\title{
Polysèmes
}

Revue d'études intertextuelles et intermédiales

Photography and Trauma

\section{The Glamour of Horror?}

\section{Olivier Morel}

\section{(2) OpenEdition \\ Journals}

Electronic version

URL: http://journals.openedition.org/polysemes/3430

DOI: 10.4000/polysemes.3430

ISSN: 2496-4212

\section{Publisher}

SAIT

\section{Electronic reference}

Olivier Morel, «The Glamour of Horror? », Polysèmes [Online], 19 | 2018, Online since 30 June 2018, connection on 20 April 2019. URL : http://journals.openedition.org/polysemes/3430 ; DOI : 10.4000/ polysemes.3430

This text was automatically generated on 20 April 2019.

Polysèmes 


\section{The Glamour of Horror?}

\section{Olivier Morel}

Olivier Morel expresses his gratitude to Juliano Salgado who allowed him to reproduce screenshots of his film in this article.

“"The earth', he said, 'has a skin and that skin has diseases. One of these diseases is called, for example, 'humanity'." (Nietzsche 113)

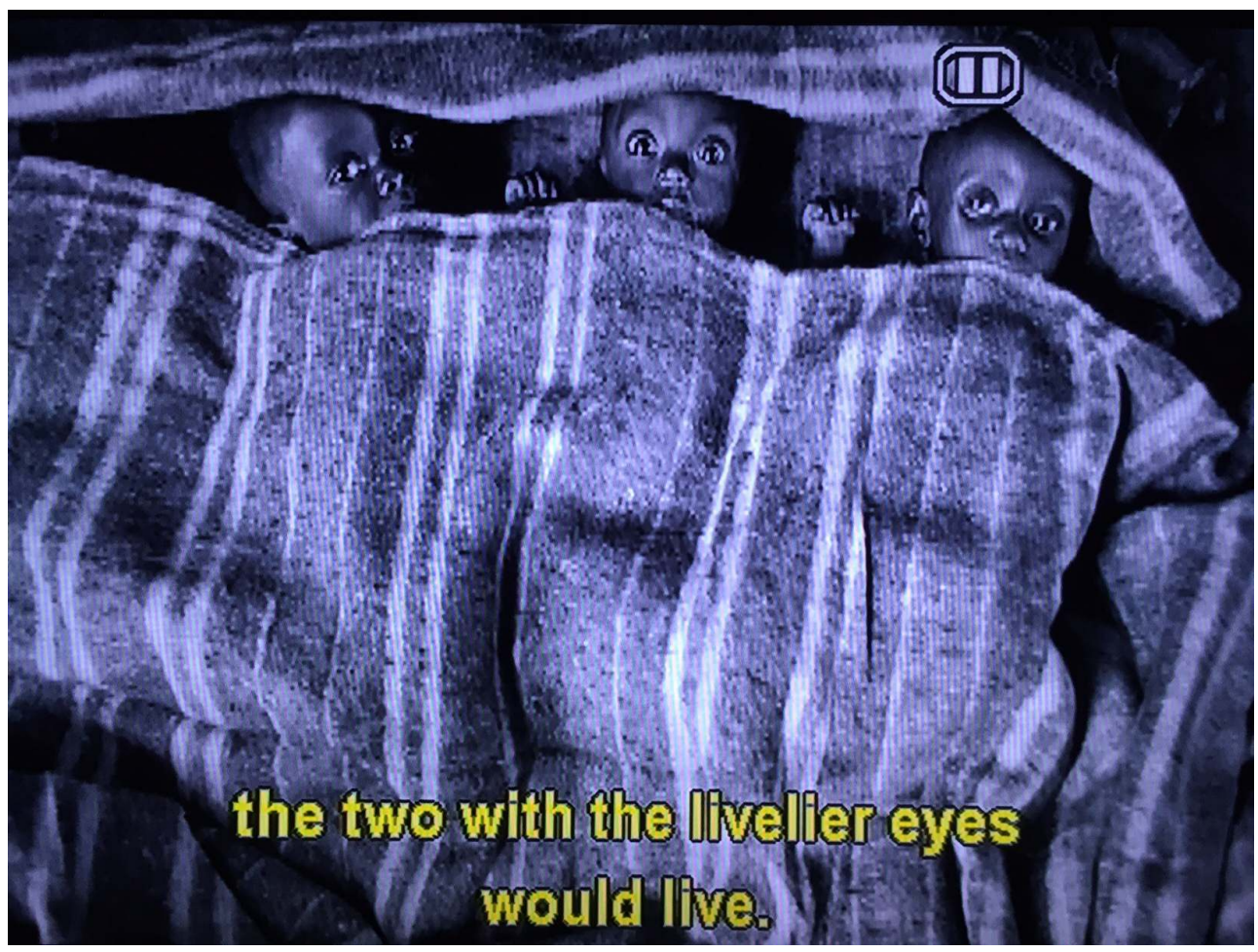

FIg. 1 : JULIANO SALgADO \& WIM WENDERS, THE SALT OF THE EARTH, 2014, 74' “[THESE] THREE CHILDREN... THE TWO WITH THE LIVELIER EYES WOULD LIVE. THE ONE WHOSE EYES ARE CLOUDED WAS DYINg. WHEN I GOT OUT OF THERE, I WAS ILL. [SALgADO APPEARS ON SCREEN] [I WAS SICK, VERY SICK] MY BODY WAS VERY SICK. I DIDN'T HAVE ANY INFECTIOUS DISEASES, BUT MY SOUL WAS VERY SICK." 


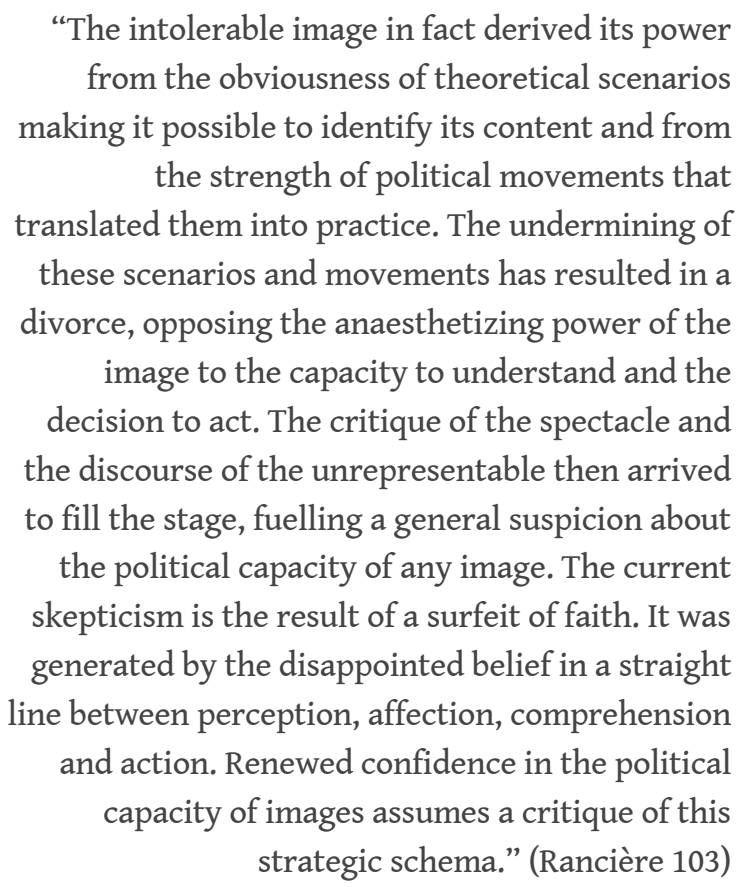

\section{The shock}

1 Among the statements that she makes on photography and its relationship to the "pain of others" in her well-known 2003 book, Susan Sontag writes that "[b]eing a spectator of calamities taking place in another country is a quintessential modern experience, the cumulative offering by more than a century and a half's worth of those professional, specialized tourists known as journalists. Wars are now also living room sights and sounds" (Sontag 2003, 18). She argues that 1914 sets off an "era of shock" for Europe. The iconic image of the Spanish republican soldier " shot' by Robert Capa's camera at the moment he is hit by an enemy bullet" in 1938 is a "shocking image, and that is the point. Conscripted as part of journalism, images were expected to arrest attention, startle, surprise." (Sontag 2003, 22-23). Her use of quotation marks to frame the word "shot" is meant to hint at a double meaning: not only did he shoot a photograph, but he also participated in the act of killing. After mentioning the slogan of the French magazine Paris Match, "The weight of words, the shock of photos", she adds: "The hunt for more dramatic (as they're often described) images drives the photographic enterprise, and is part of the normality of a culture in which shock has become a leading stimulus of consumption and source of value." (Sontag 2003, 22-23).

This is an indictment of journalism as a whole, an indictment of war photography and of photographers. War photographers and photojournalists are negatively depicted as "specialized tourists" who appear as thirsty for blood. Sontag recalls the common saying "when it bleeds, it leads". Viewers are perceived as addicted consumers seeking "more" dramatic images, more "shocking" photos. One might also highlight that "photographers" always appear as stereotypical social actors, in her analysis. Their producers and publishers, their crews and working conditions, in other words the professional sector in its complexity is not addressed in the essay. Sontag appears suspicious of the ability of photography to impact history positively as a peace-building form of expression and simply as informative. It also allows her to criticize what she 
portrays as dubious romanticism on the part of the politically committed photographer who "takes sides": "War photographers inherited what glamour of going to war still had among the anti-bellicose, especially when the war was felt to be one of those rare conflicts in which someone of conscience would be impelled to take sides." (Sontag 2003, 33, my emphasis).

More than a quarter of a century earlier, Sontag's arguments on this subject were not significantly different:

To suffer is one thing; another thing is living with the photographed images of suffering, which does not necessarily strengthen conscience and the ability to be compassionate. It can also corrupt them. Once one has seen such images, one has started down the road of seeing more, and more. Images transfix. Images anesthetize. An event known through photographs certainly becomes more real than it would have been if one had never seen the photographs-think of the Vietnam War. [...] But after repeated exposure to images it also becomes less real. (Sontag 1977, 20, my emphasis)

4 There are many assumptions in this passage. Among them is the idea that "repeated exposure" to "photographed suffering" would sanitize and anaesthetize the traumatophile, traumatopoietic (i.e., generating trauma) environment that Sontag addresses. In her view, there is a tremendous interest, a deep desire, and a scopic impulse behind the public's thirst for "more" shocking images, an exponential thirst for trauma that would nonetheless ultimately lead to a kind of disinterest or disinvestment in those images, making them simultaneously hyper-real and less real. Beyond this tension, Sontag indicts "images" themselves (photography: the signifier) as culpable of "transfixing", of "anesthetizing" ("Images transfix. Images anesthetize") through an excess of reality (or realism?), through a hyper-realization. The paradoxical logic between the desire for "more" and the decline of interest eventually provokes another contradiction, a performative one in this case, in which the suffering depicted by the photograph (what is to be seen: the signified) ruins its own, intrinsic significance, and even de-realizes its own "reality" because of its inherent violence and the vicious desire to see "more" that it triggers... This vicious circle is the cultural toxicity that Sontag addresses. Over-, or "repeated", exposure to suffering would end in a poisoning, immoral, and guilty desensitization of the "spectator"'s conscience, leading to a profound transformation of the political landscape. Instead of politicizing the audience towards "compassion" or a "strengthened conscience", as she names it, this process of mithridatization would "corrupt" and destroy the spectator's conscience and turn him/her away from the visual evidence that the photograph is bringing as a form of expression that documents events. The meaningful optical writing of history provided by photographs would sink in a form of psychological demotivation and moral disdain that turns the public away from "violence" in photography. Through this compulsion to expose and this compulsion to consume, which are coextensive dynamics, according to Sontag, the nature of photojournalism, the traumatic potential of imagery rises as the impact of violent images fades, and this damages the value and political significance of images. This idea-turnedideology widely dominates the perception of photo-journalism today, especially in the United States. "Real" violence, often labeled as "graphic images", cannot be shown.

5 Sontag's analysis predominantly revolves around a notion of "exposure" to images and is mostly organized around binary, polarized positions (or oppositions) that separate the "viewer-consumer" from what she refers to as "the photographer" and "photojournalists". Among the many occurrences of this approach is the assumption of a 
both moral and phenomenological, irreducible distance in which the perception of the world's violence is mediated by an original experience that Sontag makes explicit at the beginning of the second chapter of her 2003 essay: "Being a spectator of calamities taking place in another country is a quintessential modern experience [...]." (Sontag 2003, 18, my emphasis). Aside from assuming that the exposure to "shocking" or "violent" photography can be reduced to "being a spectator" in a prevailing passive and apolitical way that remains unquestioned, it is significant that this experience of photography is always exclusively conceived as consumerist, mediated, distant, and ultimately simplistic. Distance and passivity occur as a-theoretical prerequisites for Sontag's argument, which allows her to explain why photography fuels the trivialization and de-realization of violence, in which the deferred exposure to traumatic imagery is logically correlated to a shameful banalization of violence through a commodification of imagery (Boltanski 12).

In many ways, Sontag's approach to the politics of images is in line with the idea of a traumatophile drive leading modernity. This drive is engendered by photography and cinema understood as central artifacts and attractions that have shaped the minds and the political universe of capitalism. In this reflection Sontag is preceded by the body of work deriving from a major European tradition, namely that of the Frankfurt School, but more specifically, by the work of authors like Walter Benjamin and Siegfried Kracauer. However, while Sontag's main focus deals with images per se, with images conceived as monadic, homogeneous and often vaguely defined stereotypical productions (those of "photographers" and "journalists"), Benjamin's main focus revolves around a very holistic notion of experience associated to that of "automaton", "apparatus", as well as, somewhat marginally and yet decisively, "machines" and "machineries", and how these notions relate to the body of the photographer (Benjamin [b] 2000, 427). With these concepts, Benjamin engages a more thorough analysis of the images' closeness to the spectacle and to his notion of historical time. An "image of the past" is profoundly related, in Benjamin's thought, to hope and to the possibility of redemption. Benjamin's approach can help us understand Sontag's demeaning use of a word that is harmless but not anodyne when she depicts war photographers at work: "glamour" (Sontag 2003, 33).

\section{The "photographic" structure of trauma}

7 Benjamin avoids a major trap. In Sontag's perspective images are always seen as unable to resist instrumentalization in a process of commodification, voyeurism, de-realization and trivialization of the tragedy of history. It seems that violence is always conceived to be a heterogeneous factor for Sontag. In line with a long tradition of defiance toward iconography, this understanding of violence allows Sontag to perceive images as a menace leading to an apocalyptic "corruption" of the mind with no possible redemption. This risk implies that instead of being a possible political ally in addressing human tragedies, photography is always, by essence, a highly corrupt means, always subjected to manipulation through either pornographic violence, propaganda or, because of its gruesome character, to dissimulation. It is as if, by essence, photography suffered from a lack of essence that has ruined its meaning. The very ambiguous, even deconstructive essence of photography is at once implicitly present and avoided by Sontag. My hypothesis is that instead of surreptitiously getting rid of a debate about this essence of photography while denouncing war photographers' thirst for blood, Sontag forces us to re-consider today's a-political resistance to violent photographic imagery. In order to trust photography as a 
reliable source in the writing of history we have to rethink photography's intrinsic nature. In other words, while assuming that an undefined notion of photography (or worse, of photographers) is entirely responsible for the perversion of history Sontag misses something that is inherent in the essence of photography, something that is in line with the "shocking" nature of photography, but also something that is always the ground from which this violence is politically distributed, redeemed, addressed and perhaps, healed.

While shedding light on the image's inherent ambiguity, its intrinsic dialectic as well as its own "burning" core and even prophetic nature, Benjamin's reflection offers tools through which the difficulty of the task of addressing the shock contained in images is reconfigured. His approach to photography has the advantage of not being constrained by an over-determined, sterile, and distant subject-object relationship:

However skillful the photographer, however carefully he poses his model, the spectator feels an irresistible compulsion to look for the tiny spark of chance, of the here and now, with which reality has, as it were, seared the character in the picture; to find that imperceptible point at which in the immediacy of that long-past moment, the future so persuasively inserts itself that, looking back, we may rediscover it. It is indeed a different nature that speaks to the camera from the one which addresses the eye; different above all in the sense that instead of a space worked through by a human consciousness there appears one which is affected unconsciously. [...] Photography with its various aids (lenses, enlargements) can reveal this moment. Photography makes aware for the first time the optical unconscious, just as psychoanalysis discloses the instinctual unconscious. (Benjamin 2016, 368-385, my emphasis).

In Benjamin's work, photographs are created in a perilous, critical configuration, a conception in harmony with Sontag's reflection on brutality and violence. But what Benjamin calls the "burning" factor that "sears the character in the picture" does not appear as a heterogeneous instance that would be distant from the experience of the photographer as well as of the viewers of photographs. In a sense, photography possesses an intrinsic violence which is not only that of the signifier "violent photography" or of a photograph depicting a "scene" of violence, but the result of a tension between the signifier and the signified. Through this tension, violence seems to circulate everywhere. It operates like a demonic fire and power innervating both the signifier and the signified like a moving fluid which does not find any solid site between the protagonists to a point where "reality" is seared, burnt, and appears as a "hole", as an original default set at the core of the image. It is the image's condition of possibility-impossibility: "the spectator feels an irresistible compulsion to look for the tiny spark of chance, of the here and now, with which reality has, as it were, seared the character in the picture" (Benjamin 2016, 368-385). This powerful and demonic fluidity, also named "innervation" by Benjamin, does not imply that a photograph can ever be separated from its time, from its author, and from the time in which it is seen. It does not imply that distances and time are either abolished or insurmountable. What matters is "to find that imperceptible point at which in the immediacy of that long-past moment, the future so persuasively inserts itself that, looking back, we may rediscover it." (Benjamin 2016, 368-385). This minute in which "the future so persuasively inserts itself" opens what in Benjamin's reflection takes the place of prophecy, hope, and redemption.

But there is more. Benjamin puts the apparatus (camera), and not the perverse vampirephotographer, at the center of his notion of experience in photography. In the way the photographic apparatus operates, an innervation takes place that alienates the 
photographer from the possible perception of what he or she is photographing. It does not necessarily suggest that the photographer specifically seeks dramatic images, or "hunts" for "shocking images" which, "as part of journalism", are "expected to arrest attention, startle, surprise", as Sontag puts it. Here, Benjamin suggests that it is in photography's own nature to engender an innervated shock, to provoke a "burn" in which the real has created a hole in the image, implying that it is not only "journalism", or the photographers' vicious attraction to violence, which produces images of violence. Photography is what takes place in a flash of time in which reality vanishes before it becomes memory, before it is a constructed history. To that extent it is a synonym of trauma, which would suggest that there is an intrinsic "photographic" structure in any trauma. It is the essence of the photographic apparatus to innervate the body of the photographer and turn the camera into a testimonial apparatus, a prosthesis of perception which, faced with extreme danger and distress, captures the prophetic incandescence of an event. This "burn" is not only what photo-journalists capture in a war zone, for example; it is related, in Benjamin's work, to the way the past known as the olden times collides and explodes as a symptom of potentially involuntary memory, producing an effect of estrangement and shock embedded in the photograph. It is a constitutive feature of the image, understood as a dialectical one which emerges suddenly, in a flash, in what is the core of the historical experience as the discharge of an explosive force in Benjamin's œuvre. Through the explosive force of now-time, memory is not an act of possession, a collection of past facts, or a consumable reproduction of the remembered. Memory is the lightning production, the irruption of an explosive and sudden occurrence in the present, which is actualized by the photograph. When Benjamin writes that a burning seared the character in the picture, he indicates that in the unintentional collision of then and now that a photograph brings out, there is a flash, a shock. And what interests him is not the formation of the image but the fact that in every photograph, there is a "hole", that is a deformation, a distortion, what Georges Didi-Huberman calls a "déchirure", a tear, a symptom (Didi-Huberman 1990, 170-269 and 1992, 125-152). This default is also where the future erupts.

\section{Figuration}

11 In this sense, a dialectic image is not a foreclosed object. It is one which carries out its own crisis (burn), which lets its intrinsic deformation arise, one in which the foregone field of view "recorded" by the photographic apparatus collides with the now in the suddenness of a figuration.

"Image", writes Benjamin, "is that wherein what has been comes together in a flash with the now to form a constellation. In other words: image is dialectics at a standstill. For while the relation of the present to the past is purely temporal, the relation of what-hasbeen to the now is dialectical: not temporal in nature but figural. The image that is readwhich is to say, the image in the now of its recognisability-bears to the highest degree the imprint of the perilous critical moment on which all reading is founded" (Benjamin 2002, 463, my emphasis). Shock is not the result of an intention or as a distant exposure allowing moral judgments as in Sontag's reflection ("It is a shocking image, and that is the point", as she writes about Capa's 1938 picture). It is constitutive of the photographic image and of cinema, as Kracauer, Benjamin, and later Gilles Deleuze point out (Deleuze 166). 


\section{Haunting signifier}

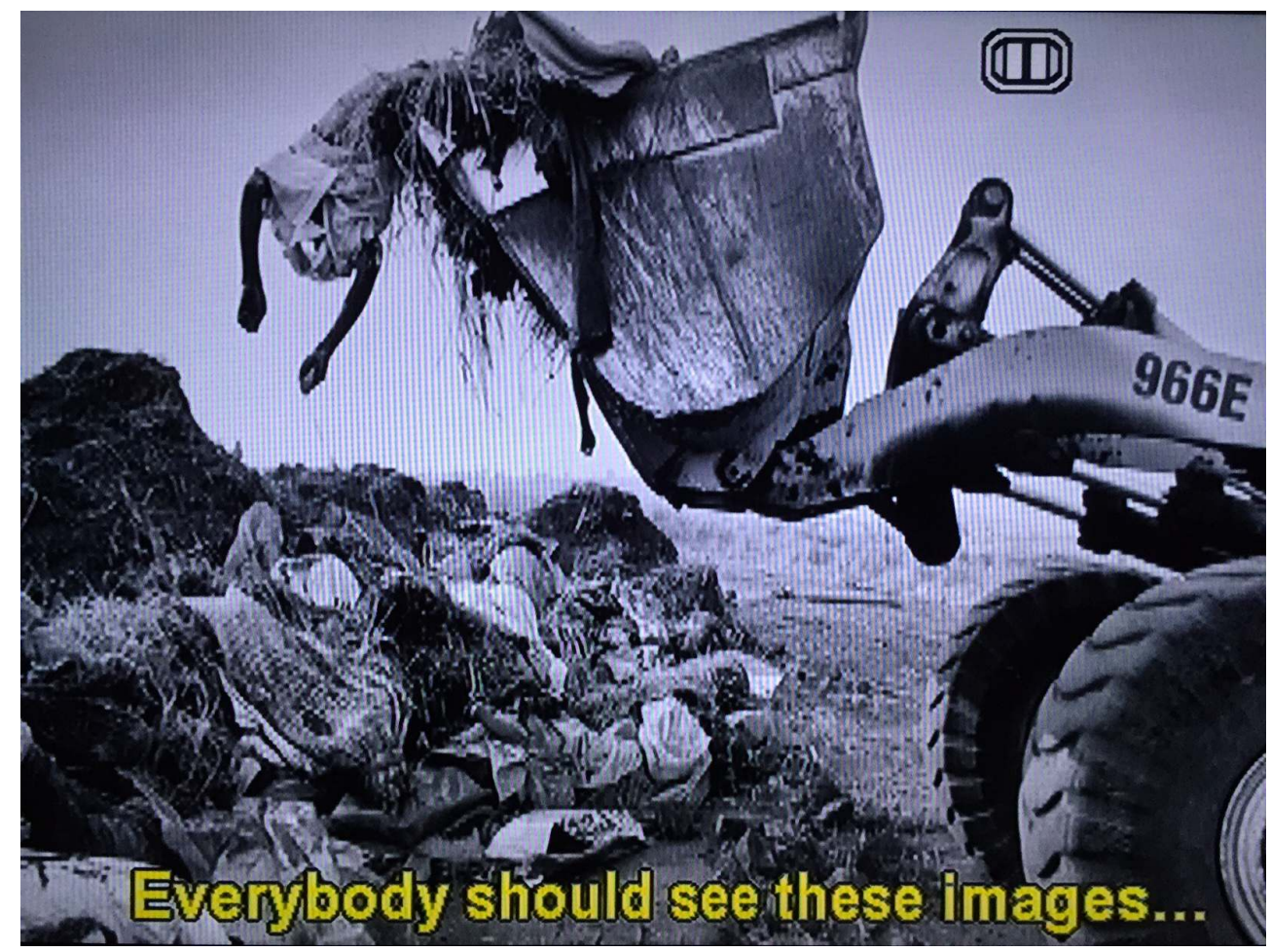

FIg. 2 : JULIANO SALgADO \& WIM WENDERS, THE SALT OF THE EARTH, 2014, 63

“THEY COULDN'T BURY ALL THE PEOPLE. SO A BULLDOZER CAME FROM THE FRENCH ARMY WHICH TOOK DOZENS AT A TIME, LAID THEM OUT ON THE GROUND AND COVERED THEM WITH EARTH. EVERYBODY SHOULD SEE THESE IMAgES TO SEE HOW TERRIBLE OUR SPECIES IS."

This photograph by Sebastião Salgado appears in a series of three in Juliano Salgado and Wim Wenders's film The Salt of the Earth. In the film, the photographic triptych exists on the screen through its cinematic fragmentation. As such it erupts as a flash of messianic time that turns Sebastião Salgado into a Benjaminian rag-picker whose camera is the fragile motorized-vehicle (both narrative and visual) that allows the spark of hope to occur: it does not let the enemy triumph as it redeems shreds of the underworld in the midst of catastrophe. The cinematic motorization of Sebastião Salgado's still photographs is an artistic statement by the filmmakers that makes the innervation process explicit. Sebastião Salgado's oral formulation brings out the fact that he is dealing with political catastrophes. His photographic discourse on the visible is never separable from his political construction of what is to be seen. Salgado has often found himself to be the only photographer present on the scenes and events he documents and this consideration goes beyond the purely spatial notion known as being "in the right place at the right time". In Salgado's work, it touches the Benjaminian photographic deconstruction, "that imperceptible point" (Benjamin 2016, 368), that highlights an unconscious structure erupting from consciousness. What he shows is what we are not able to watch, and in a way, he embodies what photography and cinema are all about when they politically make visible what is in front of us that we cannot see. Or worse, that we do not want to see. The burn. 
14 Featuring three different angles, the silent immobility of the triptych-sequence is slowly commented on by Salgado in a soft, almost murmured voice, with a stunning economy of words. The serial dimension of this (un)spoken caption that the cinematic form allows, turns this film into an intense artifact in which the boundary between still images and moving images is always blurred, suggesting that our relationship to reality is constructed by the artist, photographer, and filmmakers, in order to highlight what is, in fact, a shared perception more than a distant interaction. The main substance of this film consists of unveiling this political dimension of how profoundly our visible and sensible universe is constructed by an artistic disposition to view humanity. If these photographs are meant to become public it is because they make sense, they are meant to participate in the common sense of what Jacques Rancière calls the "partage du sensible"-which both means the partition of the sensible, of the perceptible, and its distribution (Rancière). Reality, especially through the focalization and its subtle construction of signifier, is anything but a fragile, fragmented, political construct. Salgado's photographs are profoundly critical, exploded, fragmented. This frozen, intolerable, "dialectic image" (Benjamin) is a concentration of shock, of trauma. Indeed, what erupts "between" the pictures is the burn, the tear of what is to be seen (Didi-Huberman 1990, 170-269). The burn of the image itself that puts an image into crisis allows the optical unconscious to do its mysterious work. What do we see? We see the hole, the abyss of pain. We see that we do not [want to] see what is to be seen. We see what was not seen in this year 1994. We see this latency within the experience. Salgado's pictures of Rwanda document this trauma. A genocide and its consequences: "During the genocide in Rwanda, the number of reporters 'never rose above a maximum of fifteen' and after April 14 (eight days after the killings started) only five journalists are said to have remained in Kigali-an absurdly low number [...]" (Möller 115). We see the missing picture, the experience of a missing experience that defines trauma (Panh) and constitutes the camera as a traumatophile apparatus.

These three images of the bulldozer handling corpses are haunting. They are also haunted. If those haunting moments are in line with what Benjamin names the optical unconscious, it is because, throughout the film such "intolerable" images propose a distribution of the visible and the sensible that offers a double resistance. First, they defy the idea of an "unrepresentable" (Rancière 103) in images of violence. Secondly, when Salgado asserts that "everybody should see these images", he conceives them in opposition to the idea of an anesthetizing aspect that plagues images of violence, this reluctance to deal with violent images discussed by Sontag, also known as "compassion fatigue". Through the sequentiality of his work, the triptych leads to a proto-cinematic discourse of images. This cinematic construction of photography attains a paroxysm with The Salt of the Earth where the commented montage of photographs goes beyond a hagiographical presentation of one of the most influential photographers of the time. It sheds light on Salgado's political cry at the core of his work. While it is documenting an idiosyncratic human horror that was taking place in a gigantic refugee camp set in Goma, Zaïre, in 1994, while it captures what is by definition a unique event, this seriality finds its psychological, wounded (traumatized) refuge, in a highly traumatizing visual universe, that of Alain Resnais's Nuit et Brouillard. Salgado's injunction that "everybody" sees these images is more than just another call for action. Through its historic referentiality Salgado's triptych highlights the haunting political responsibility that any photograph should generate when it opens historical mise-en-abymes similar to the movement identified by Benjamin: when, in a photograph, "the immediacy of that long-past 
moment, the future so persuasively inserts itself that, looking back, we may rediscover it" (Benjamin 2016, 368). The future of Salgado's dark discovery... this is what is unbearable for Salgado, and this haunting signifier points less at a historic analogy between 1945 and 1994, than at the need to politicize a certain regime of the sensible, without which we will not see these images.

\section{Pellicula}

In Juliano Salgado and Wim Wenders's powerful montage, the seriality of images and their regime of referentiality generate an uncanny, subliminal movement, that seems to never end. If this repetition is trauma itself, the symptom called "repetition" is what prompts the political consciousness without which there is no image. This is what Benjamin calls an "arrested dialectic" in which a photographic image is not just temporal, but an act of figuration, a performance that makes the real and the visible collapse in a political reconfiguration of "reality".

After the bulldozer sequence, a picture of two little boys comes into focus. In this image, it appears that one of the boys is playing or dancing in the background. The other one is kneeling naked in the foreground with a mask of intense suffering. His mouth is wide open in a cry that the photo lets us hear in silence, an echo of the voiceless corpses in the previous scene. This structure is omnipresent. The two boys are orphans from the SOS orphanage center in N'Dosho near Goma that held 4,000 Rwandan orphans at the time the photograph was taken in 1994. The next image to appear on the screen shows three suffering infants lying on their backs. All three of them are gazing right into the eye of the camera, thereby watching us and prolonging the injunction to see:

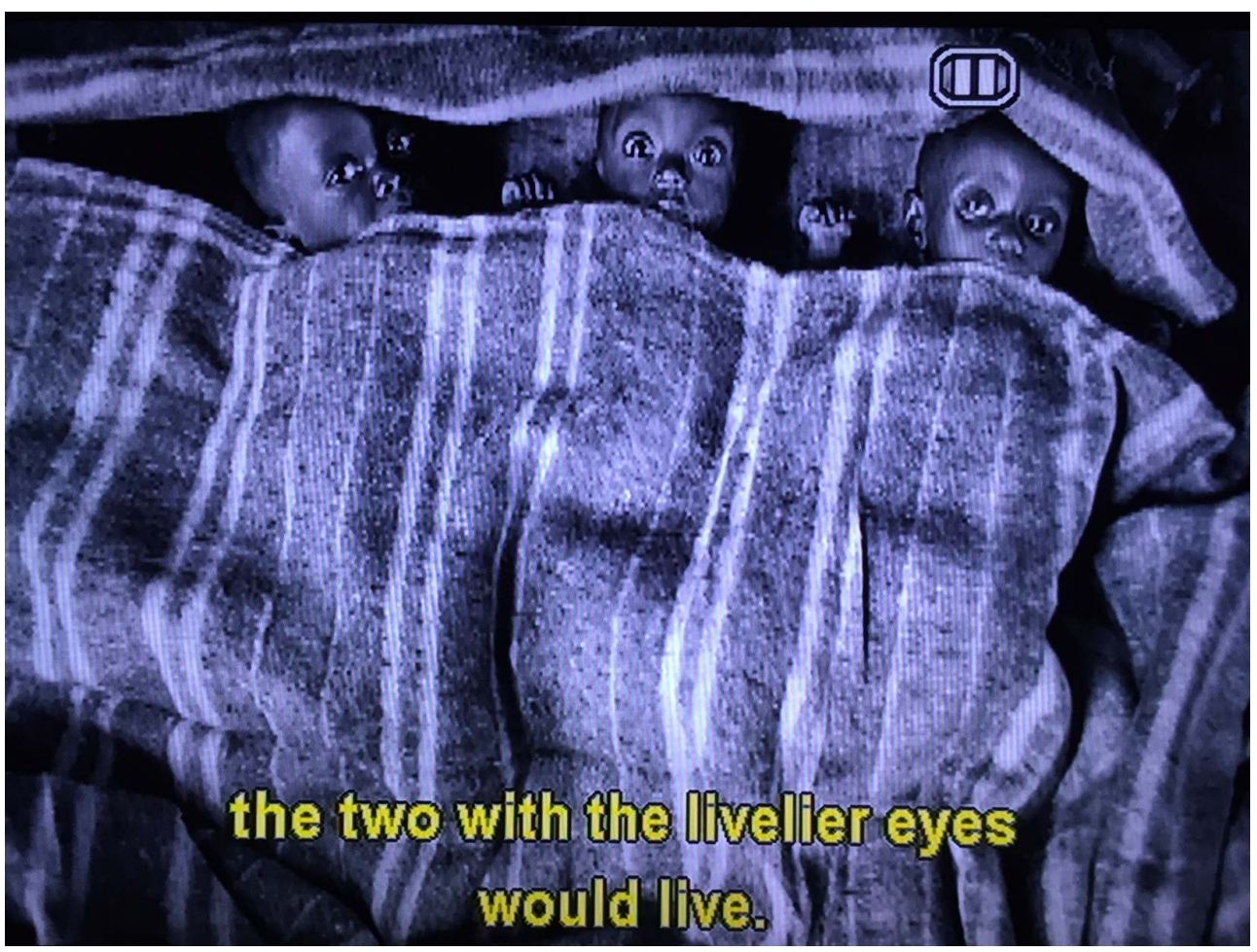

Fig. 1: Juliano Salgado \& Wim Wenders, The Salt of the Earth, 2014, 74' 
18

[These] three children... the two with the livelier eyes would live. The one whose eyes are clouded was dying. When I got out of there, I was ill". When he pronounces those words, Salgado's face appears on the screen, just his face, set on a dark background: "My body was very sick. I didn't have any infectious diseases, but my soul was very sick". The deconstruction "today, he is dead; he will die and he is dead, he is dead and he is dying" is what happens, what comes to us, what falls on Salgado like a disease. This disease is our subject, it is what happens in the traumatic innervation that attaches Salgado to his photographic machinery and to us while experiencing a distant, incommensurable suffering that gets under our skin, far from the "glamour of going to war" (Sontag 2003, 33). Then, Salgado's face fades to black, a cello is playing, it is midnight in the film.

The film captures and projects Salgado's wandering in the abyss of human catastrophes. The horrors circulate between his apparatus and his soul. The film documents this nervous pain. It is subsumed in an epiphany of the skin:

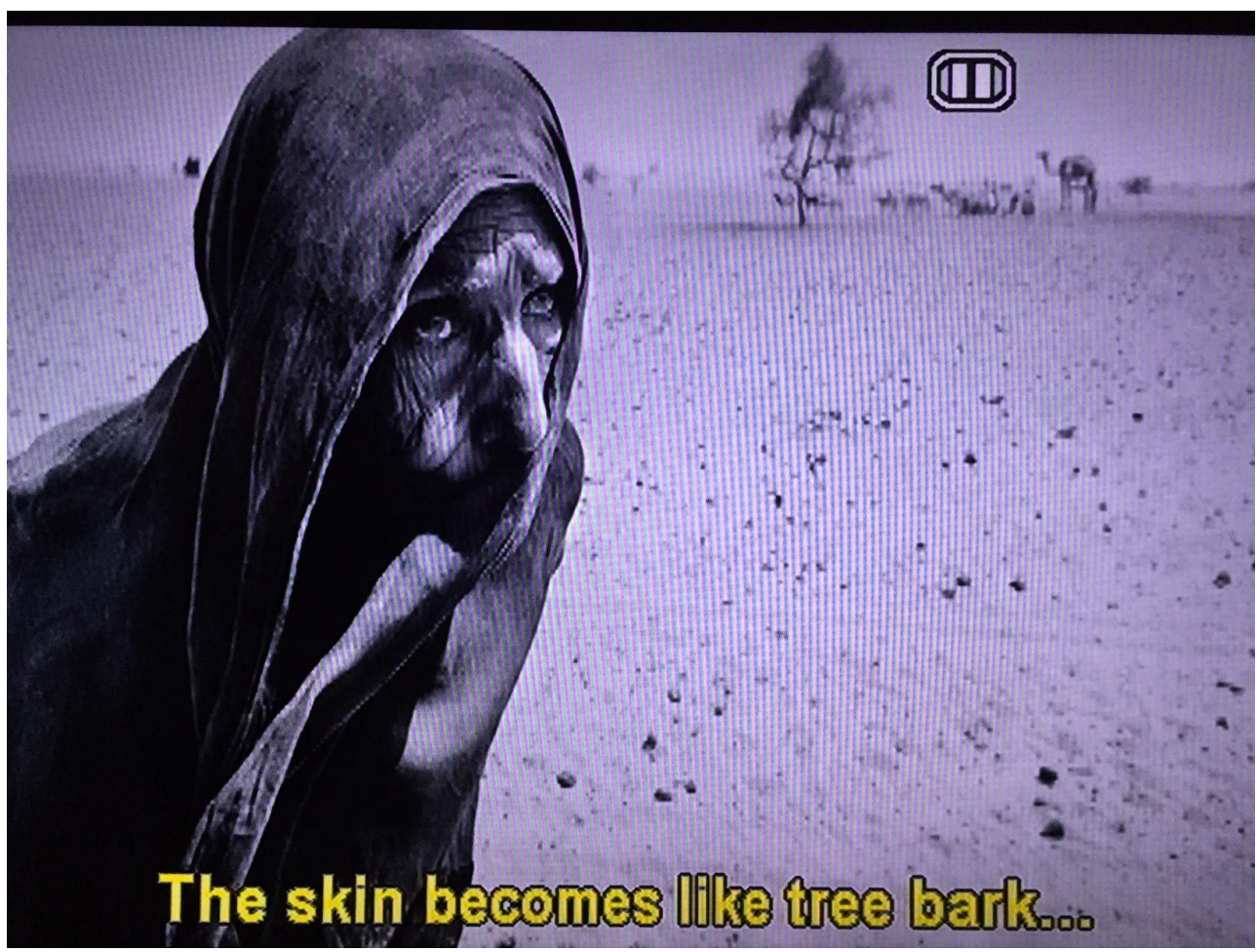

Fig. 3: Juliano Salgado \& Wim Wenders, The Salt of the Earth, 2014, 55'35"

This photograph was taken in Mali, in 1985, during what Salgado calls a politically generated catastrophe. It is The End of the Road project. "The skin becomes like tree bark...", Salgado says in his commentary, "like a tree marked by the desert wind, by sandstorm after sandstorm” (Salgado J., \& Wenders 2014, TC 55'35”). Trees play a central role in The Salt of the Earth. In Salgado's journey, they become a cinematic redemption, a rejuvenation of Salgado's family's dry and dying land in Brazil in the Valley of the River Doce. Dying trees seen in the photographs taken in the Malian desert are reminders of a long history and of the earth's decay. Here, trees also bear witness to the earth's damaged skin.

21 In this 1985 image, we see a dying tree in the background and a frail human being in the foreground. Salgado's metaphoric depiction of the "tree bark" skin of the protagonist creates a visual association that links the human's skin to the dry tree in the background. 
In this picture, dying trees are metaphors for ghosts. They are visions of the dying humans he photographed in the Malian desert. For Salgado, in the digital age, handmade prints and books of his photographs are vital artifacts. As a membrane, the human skin is a kind of "pellicule". In French "pellicule" is derived from the Latin "pellicula", "pellis": skin (Littré offers this definition of "pellicule": "membrane très mince", "very thin membrane"). "Pellicule" is also used in photography, "pellicule" being the photographic film before it is developed. This thin "pellis" is the physical materiality of film, the printed film is the literal embodiment of Benjamin's innervation. It is the skin of trauma. In a way, the solar wind of light is the storm that marks the film-pellicule of the photographer. This pellicule infinitely multiplies ephemeral traces. From this perspective, it could be that Salgado offers a multilayered evocation of the skin. It allows him to show how an intimate nervous pain becomes a film and a printed image of burnt time. It highlights the importance of the photographic body-machine in this process. The skinscreen on which Salgado projects his work in The Salt of the Earth shows how the camera is a part of his own body-machine, set underneath the skin of the photographer-which recalls that being haunted in its archaic sense is precisely tied with this subcutaneous phenomenon where an estranged being is lodged underneath one's skin, set in the intimacy of one's own body, of one's home. Salgado's hauntology captures the last beams of light of this skin disease described by Nietzsche in Thus Spoke Zarathustra: “'The earth', he said, 'has a skin and that skin has diseases. One of these diseases is called, for example, 'humanity'." (Nietzsche 113).

Salgado's aforementioned observation on skin is preceded by similar reflections:

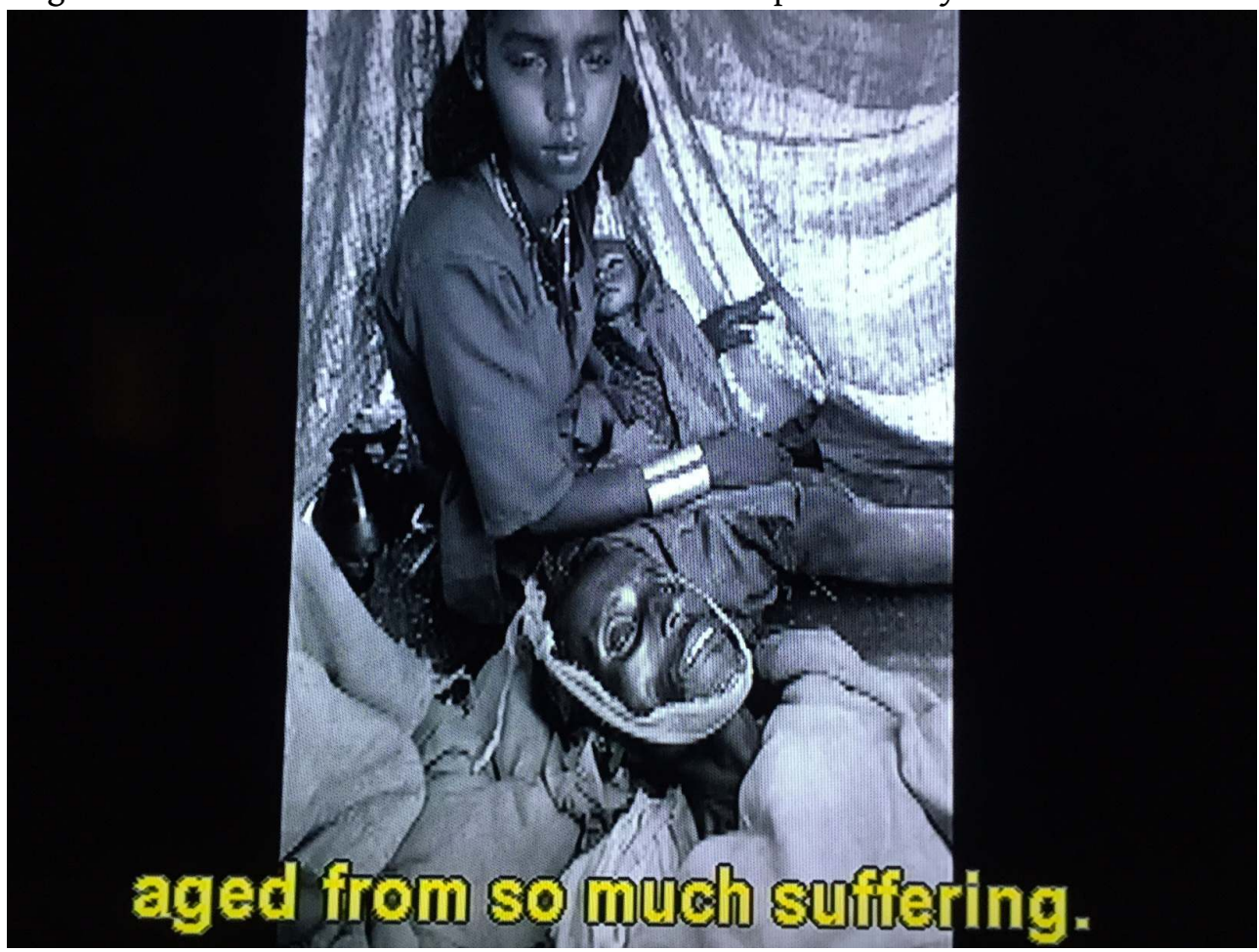




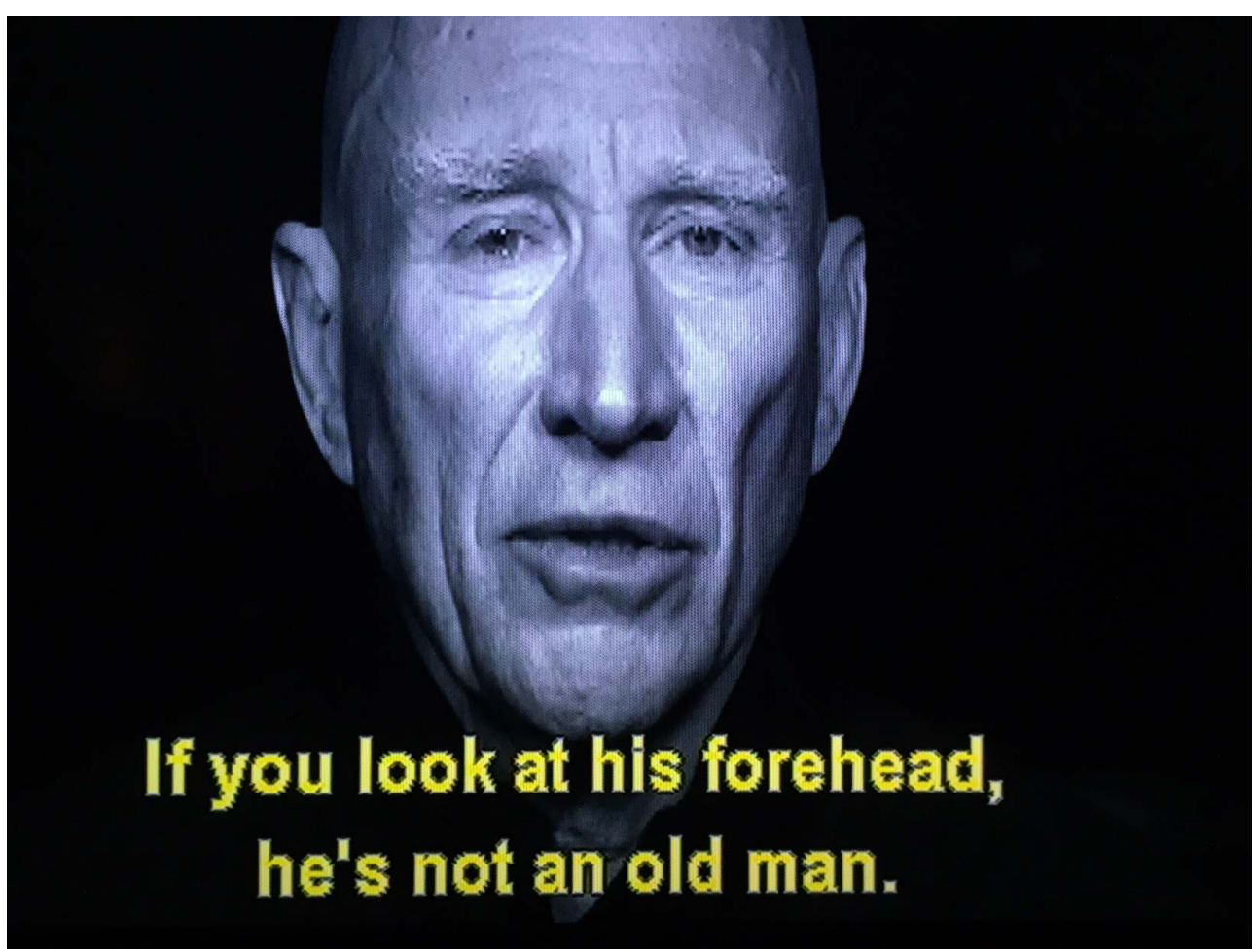

FIg. 4 AND 5: JULIANO SALgADO \& WIM WENDERS, THE SALT OF THE EARTH, 2014, 50'00"

“SUCH YOUNg FACES, AgED FROM SO MUCH SUFFERINg. IF YOU LOOK AT HIS FOREHEAD, HE'S NOT AN OLD MAN. WHAT'S OLD ABOUT HIM IS THE EMPTINESS IN HIS EYES. LOOK HOW YOUNG SHE IS, LOOK AT THEIR BABY! HE'S HER HUSBAND. MOST DEATHS WERE AT NIGHT FROM THE COLD. DYINg HERE WAS REALly A CONTINUATION OF LIFE. THE PEOPLE WERE USED TO DYINg."

What connects these considerations of the skin that resembles a tree bark and the photography of the three little boys that will follow and prompt Salgado to become psychologically sick from this journey into darkness, is the eyes: the "emptiness in [the] eyes" of the "old"-young man dying, and the "clouded eyes" of one of the three little boys who is dying before our eyes. With his physical and mechanical eye, Salgado is capturing something that camera have the special ability to capture: the moment of death. But more specifically, it is the secret of death as well as a secret relationship to death.

It is intriguing that, in Susan Sontag's words, "glamour" is what "war photographers" inherit when they go to war:

War photographers inherited what glamour going to war still had among the antibellicose, especially when the war was felt to be one of those rare conflicts in which someone of conscience would be impelled to take sides. (Sontag 2003, 33)

"Glamour" is the central notion of the philosopher Serge Margel's text on photography and film titled La Société du spectral:

Faire la grime in French means to make a face or to sulk. [...] however, grima also denotes the "specter", which can still be found in the English phrase grim reaper, often serving as an allegory of death. The word glamour contains all of these connotations: secretions, the grimoire, and the face of death. A manner, an expression, appearance, a look that expresses a secret relation to death or a relation that secretes something related to death, or that in a certain sense stages a viscous secretion or a grim, deathly pallor. (Margel 11)

A few lines further, Margel adds:

Glamour concerns the eyes, not in the sense of vision, the visual, or the visible, but rather of the ocular, the eye's globular sphere that encompasses (englober) 
everything, secreting a viscous, mucus-like liquid (les glaires), that agglutinates

images. (Margel 11)

This essay by Margel is a commentary on Sternberg's text on glamour in which the latter explains what Marlene Dietrich is for him. Sternberg writes: "Glamour in a photograph is the treatment of surface-a surface that is not even skin deep: it is only as deep as the paper which reproduces the image." (Von Sternberg 172, my emphasis). It is a pellicula.

The surface, the eye, the thin membrane, the skin, the deathly pallor, the face of death and its secrets, all of this is at stake in Salgado's photographs and comments, here. The only aspect that seems to be missing is the viscous secretion. The horror of death by drought is what Salgado's camera innervates. We note this emphasis on the eye, the globular organ, that Salgado highlights when he points out the little kid whose eyes are not lively, although he is not yet dead. A similar observation drives the comment about the wife whose husband is dying.

Is a dry glamour conceivable? A glamour where the globular spheres known as eyes would remain dry, that of a tree bark-like skin, the clouded eye of a dying child who is no longer able to cry... a glamour of horror? We hear the cry of the young woman's husband, we see the eyes of an infant glossing over, of the female refugee seeking water and food in the drought of the desert in the Gourma Rarhous region. This drought is what impresses Salgado's skin-pellicule. Dry skin, dry eyes, no tears. The desert grows. There is no viscous secretion of the skins, on the faces, in the empty, clouded eyes of Salgado's subjects. There are no secretions, but there are secrets. Salgado's work and comments highlight common features of what Margel conceptualizes as "glamour": a secret relationship to death , a "secretion or a grim" of death that is secreted at the commissure of the eyes, around their globular sphere, in their eyes filled with the suffering that agglutinates in the images and "makes" those images. Their eyes are filled with an uncertainty that places them between the worlds of life and death. They are like marionettes and automatons who will always seem human until it is time for them to cry.

\section{Glamour of horror}

In the glamour of pain and horror, the surface of an ambiguous living/non-living body known as skin is an overinvested one. This is the body-machine's regime of nondifferentiation that usually constitutes the glamour of the star understood as an automaton-marionette. The intolerable horror, the violence of the image arises from this spectral evidence that what is to be seen is also what puts the image in crisis, and depends on the viewer's inability to distinguish between regimes of the visible "living". Is the subject seen alive or dead? We may never know, just like the unfortunate bystanders of a crime scene or a deadly accident: is this prostrate body still alive? There is a double scene here that deals with the fact that the subject, by essence, is photographed as if he or she were always already dead (deferred presence), but at the same time, what is to be seen on the picture is not dead or alive for sure. It is also Derrida's assumption that in any photographic or cinematic process, a doubling of the subject is at work that always already turns the subject who is filmed and/or photographed into a ghost. What the photograph captures is this machinery of indetermination in which the oscillation and uncertainty between the "real" and the spectral never seems to end. This is what Benjamin's innervation is about where it is impossible to distinguish (or find distance) between the living, the dead and the machine (automaton). This is also where the 
glamour lies. The double, the replica, the reproduction becomes a compulsory, neverending circulation and proliferation of the undecided. This factor does not occur as a secondary event that would erupt within the production of images, but as the very nature of photography. In this innervation process, the glamour of horror is the other name of photographic trauma and of its complex deconstructive structure. The compulsion to repeat or to repress, the drive "for more" (Sontag), or less (compassion fatigue) is a constitutive element of this deconstruction in which repression or attraction should never be separated.

Through the increasing fluidity of skinless a-filmic "digital" images, we have seen this compulsion at work with an unprecedented intensity over the past years. If it has even become a substantial part of the performance of violence in the use of violent imagery as a war machine by ISIS and other terrorist groups, it also depends on what Rancière points out, that the weakening of political scenarios over the past decades has also weakened photography as a crucial component of the "shared sensible" (Rancière) that shapes our political universe.

In response to Sontag's perspective, one might propose therefore that innervated photographers' political bodies were tied to highly violent, intolerable events in recent history. Courageous photographers creatively shared photographs as prophetic acts of resistance against official propaganda. This goes far beyond the restrictive framework of distant consumption and voyeurism. These images are temporal, they achieve a figural status when their dialectical, deconstructive nature is affirmed, in a burning instant.

Secretion, grimoire, not yet dead (?)-face of death... The Egyptian photographer Al Youm Al Saabi took a picture at the very moment when Shaimaa el-Sabbagh was killed during peaceful protests in honor of the Arab Spring uprising of 2011. The man who is holding her is named Sayyed Abu el-Ela. There is an armed man in the background. Al Youm Al Saabi shot six images of the immediate moment when Shaimaa was touched. What he has photographed one street away from Tahrir Square is the burning instant of a woman's death. There is no need to mention how highly political the entire scene is. This image quickly became an icon (Mortensen 79-113) of the resistance against abusive power in Egypt and beyond.

31 Trauma is the spectral repetition (compulsion) of photographic uncertainty and the picture aggravates the fact that we are politically helpless when faced with what happened through an "obscenity effect" that generates Sontag's suspicion towards photography. That said, it is also because this complex structure is in place that this picture plays a historic role in which the body-machine of the camera tears the aporia of the visible. In this way, Shaimaa's unacceptable death, her name, but more importantly, her dying body, become the icon of an Arab Spring that will never cease to be present if we follow Benjamin's injunction. This is where the photo-cinematic machinery becomes the vehicle of a historic, revolutionary, prophetic machination that Salgado has operated throughout his life: it is pertinent. "Pertinent", as a word, is etymologically informed by the vocabulary of touching. These photos are traumatizing because they ignite a power that allows us to be touched by one's death as our own spectral death, to be touched by a death-like break (trauma), while promising something that touches us without touch, beyond us in a never-ending circulation of political revolt. This is what Shaimaa's deconstructive image is promising: injustice will end. 
explains why the main resistance to photography is perhaps photography itself. This intrinsic crisis is trauma, but it is also photography's prophetic power, when the "immediacy of that long-past minute" (Benjamin 2016, 7) of one's death is prophetically, that is to say politically, not dead. It still burns, which means that it both enlightens and is consumed from the inside of an interrupted future. This is the dry future of political photography, its horrendous glamour. This eruption of the future within the burn of the image is what shakes the viewer's body as the image's most intimate nest, the core of photography where "the future so persuasively inserts itself" (Benjamin 2016, 7), underneath the image's estranged skin, the film, our dry skin. This is why Salgado's ghosts keep haunting us and why through his partage (sharing and dividing) of photographs, through his partition-distribution of the intolerable, he is also sharing more than another violent commodified photograph. Salgado's gentle, almost voiceless scream has come back worn out from the underworld and it whispers a rebellious word: "every body should see these images".

\section{BIBLIOGRAPHY}

Benjamin, Walter. A Short History of Photography. Trans. Stanley Michell, last accessed on May 18, 2016, https://monoskop.org/images/7/79/ Benjamin_Walter_1931_1972_A_Short_History_of_Photography.pdf Benjamin, Walter. The Arcades Project. Trans. Howard Eiland, Kevin McLaughlin. Cambridge, Mass.: Harvard UP, 2002.

Benjamin, Walter [a]. «L'œuvre d'art à l'époque de sa reproductibilité technique (dernière version de 1939) ». CEuvres, t. III. Trans. Maurice de Gandillac, Rainer Rochlitz and Pierre Rusch. Paris : Gallimard, 2000.

Benjamin, Walter [b]. « Sur le concept d'histoire ». Euvres, t. III. Trans. Maurice de Gandillac, Rainer Rochlitz and Pierre Rusch. Paris : Gallimard, 2000.

Benjamin, Walter [c]. « Petite histoire de la photographie ». Euvres, t. II. Trans. Maurice de Gandillac, Rainer Rochlitz and Pierre Rusch. Paris : Gallimard, 2000.

Boltanski, Luc. Distant Suffering, Morality, Media and Politics. Trans. Graham Burchell. Cambridge: Cambridge UP, 1999.

Deleuze, Gilles. Cinema 2: The Time-Image. Trans. Hugh Thomlinson and Robert Galeta. Minneapolis: U of Minnesota P, 1989. [First French edition: 1985]

Didi-Huberman, Georges. Devant l'image. Paris : Éditions de Minuit, 1990.

Didi-Huberman, Georges. Ce que nous voyons, ce qui nous regarde. Paris : Éditions de Minuit, 1992.

Margel, Serge. "The Society of the Spectral". Trans. Eva Yampolsky. Diacritics 40.3 (Baltimore: Johns Hopkins UP, 2012): 6-25. 
Mortensen, Mette. "The Unintentional News Icon, The Canonization and Political Mobilization of the Footage of Neda Agha Soltan in the Post-Election Revolt Iran (2009)". Journalism and Eyewitness Images, Digital Media, Participation and Conflict. London: Routledge, 2015, 79-113.

Möller, Frank. "Rwanda, Revisualized: Genocide, Photography, and the Era of the Witness". Alternatives: Global, Local, Political 35.2 (April-June 2010): 113-136.

Nietzsche, Friedrich. Thus Spoke Zarathustra. A Book for Everyone and Nobody. Trans. Graham Parkes. Oxford: Oxford UP, 2005.

Panh, Rithy. The Missing Picture (L'Image manquante). Catherine Dussart Productions (CDP). Arte France Bophana Production, 2015.

Rancière, Jacques. The Emancipated Spectator. Trans. Gregor Elliott. London/New York: Verso, 2009.

Rancière, Jacques. The Politics of Aesthetics: The Distribution of the Sensible. Trans. Gabriel Rockhill. London: Continuum, 2004.

Salgado, Juliano \& Wim Wenders. The Salt of the Earth. Decia Films (co-production)/Amazonas Images (co-production)/Solares Fondazione delle arti (co-production), 2014.

Salgado, Sebastião. Africa. Hong Kong / London / Köln / Los Angeles / Madrid / Paris / Tokyo: Taschen, 2007.

Sontag, Susan. Regarding the Pain of Others. New York: Picador, 2003.

Sontag, Susan. On Photography. New York: Dell, 1977.

Von Sternberg, Joseph. “The Sternberg Principle”. Esquire 60.2 (October 1963): 90-97.

\section{NOTES}

1. This photograph was published in Sebastião Salgado's book Africa (Africa 175). The picture was taken in an orphanage attached to the hospital at Kibuma Number One camp, in Goma, Zaïre, 1994.

\section{ABSTRACTS}

In this reflection about today's cultural and political perception of "intolerable images", we question the argument that the optical writing of history provided by "violent photographs" would sink in a form of psychological demotivation and moral disdain that turns the public away from photojournalism. Focusing on the photographic image's inherent ambiguity, on its intrinsic dialectic as well as its own "burning" core, allows us to address the shock contained in images per se. Like any trace, photography carries out its own destruction. But what the photograph captures is also a machinery of indetermination in which the oscillation and uncertainty between the "real" and the spectral, the living and the non-living, never seems to end. While studying Sebastião Salgado's work among others, our reflection on Susan Sontag and Serge Margel shows 
that there is a "glamour of horror" in which trauma is the name of a deconstructive structure that lies at the core of the photographic and cinematic machinations.

Dans cette réflexion sur la perception culturelle et politique des «images intolérables » nous questionnons l'argument selon lequel l'écriture optique de l'histoire forgée par les "photographies violentes" sombrerait dans une forme de démotivation psychologique et un dédain moral qui éloignent le public du photojournalisme. Notre attention à l'égard de l'ambiguïté inhérente de l'image photographique, de la dialectique intrinsèque et du cœur "brûlant» de celle-ci, nous permet de raffiner la notion de "choc» ancré dans cette image. Comme toute trace, la photographie est portée par sa propre destruction. Mais ce que la photographie capture est aussi une machine d'indétermination dans laquelle l'oscillation et l'incertitude entre le « réel » et le spectral, entre le vivant et le non-vivant, ne semble jamais finir. À travers une étude du travail de Sebastião Salgado, parmi d'autres, notre réflexion, portée par Susan Sontag et Serge Margel, montre qu'il y a un "glamour de l'horreur » dans lequel le trauma est le nom de la structure déconstructive qui est lovée au cœur des machinations photographiques et cinématographiques.

\section{INDEX}

Mots-clés: photographie, photojournalisme, trauma, choc, déconstruction, glamour, écran, culture visuelle, appareil cinématographique, spectralité, fantôme, automate, marionnette, star, démotivation

Keywords: photography, photojournalism, trauma, shock, deconstruction, glamour, screen, visual culture, cinematic apparatus, spectrality, ghost, automaton, marionette, stardom, demotivation

oeuvrecitee Salt of the Earth (The)

\section{AUTHORS}

\section{OLIVIER MOREL}

Olivier Morel is a filmmaker as well as being Assistant Professor at the University of Notre Dame. His academic work focuses on the correlation between trauma and fiction, as well as trauma and creation. This dimension is embodied in both his cinematic work and his academic writing. He is the author of numerous scholarly and cinematic works, including the award-winning documentary film On the Bridge (2010), the graphic novel Walking Wounded (drawings by Maël), and two other books: Visages de la Grande Guerre and Berlin légendes ou la mémoire des décombres (2014). 